\title{
Exploring Gender Wage Gap in Urban Labor Market of Bangladesh
}

\author{
Muhammad Shahadat Hossain Siddiquee ${ }^{1} \&$ Md Amzad Hossain ${ }^{2, *}$ \\ ${ }^{1}$ University of Dhaka, Bangladesh \\ ${ }^{2}$ University of Virginia, USA \\ *University of Virginia, USA. E-mail:mh2vh@virginia.edu
}

Received: March 11, 2018 Accepted: March 21, 2018 Published: March 31, 2018

doi: 10.5296/rae.v10i1.12873 URL: https://doi.org/10.5296/rae.v10i1.12873

\begin{abstract}
Using the Labor Force Survey 2010 dataset this paper examines gender wage gap in a large sample of urban workers in Bangladesh and explore whether gender wage gap varies across the wage distribution. Mincerian OLS regression and its Blinder-Oaxaca decomposition results reveal that the estimated wage gap between men and women workers is $21.2 \%$. Adjusting women's endowments levels to those of men increases women's wage by $12.1 \%$ and a gap of $8.0 \%$ remains unexplained. The decomposition results based on the unconditional quantile regressions demonstrate that the estimated total gender wage gap is higher at lower end of the wage distribution compared to the higher end.
\end{abstract}

Keywords: Gender, Wage Gap, Urban, Bangladesh, Mincerian regression, Blinder-Oaxaca decomposition, Quantile Regressions

JEL Classification: C21, J16, J21, J24, J31, J71 


\section{Introduction}

One of the most important mechanisms of transmitting the benefits of economic growth to male and female groups in the society is the labor market. Today women have become a significant part of the labor market in Bangladesh and therefore, play a significant role in growth trajectories. Women's share in the labor market across the globe is increasing at a faster rate than that of the men, a phenomenon termed as 'feminization' of the labor force (Standing, 1989; Cagatay and Ozler, 1995). Women participation in Bangladesh labor market is accelerating over time. Cheaper women labor in Bangladesh are inducing employers to alternate the male labors with the female ones in jobs like agriculture, services, construction, and manufacturing which were traditionally done by men (Rahman, 2013). Moreover, women are unassuming, not unionized and flexible in hiring and all these result in an increasing share of women in the labor market of Bangladesh. The significant rise in women employment in garment industries of Bangladesh (which are usually located in the urban areas) contributes to reducing gender gap in employment, income, social prestige, control over resources and decision making (ibid).

Gender wage gap across the globe is an oft-cited indicator of gender-based inequality in labor markets. The average 'global' gender pay gap is $16.5 \%$ whereas it is $21.1 \%$ in Asian countries (ITUC, 2008 in Kapsos, 2008). Women, in general, lag behind men in many spheres in developing countries and thus gender differences are noticeable in several domains in terms of access to and control over resources, work opportunities, participation and rewards. The nature and extent of these differentials varies across and within countries and is based on customs and economic system of a nation. For example, male-female wage differential is either country (or region specific) or context (rural-urban) specific. In the context of labor market opportunities, women, on an average, earn less than men for a similar work and the gap varies across and within countries. For example, Europe, Oceania and Latin America are far better when compared with Asia and Africa, where usual female economic participation is low and there are large informal economies (ibid).

Labor market in Bangladesh is segregated by gender as many women are involved either in non-market activities at home or in the informal sector. Among those who work in the formal sector are generally employed in the 'female labor-intensive industry' like readymade garment, shrimp processing and pharmaceuticals (Ahmed and Maitra, 2010). Moreover, women face upward mobility constraints in most of the workplace. Inferring wag gaps due to labor market segregation might provide some insight into evidence of discrimination against women in the labor markets of Bangladesh. In both rural and urban areas of Bangladesh, women in paid employment often receive lower wages than men and this gap still remain so even after controlling the covariates like age, education, occupation, regional variations (ibid). Though rural female wage rates remain constant at $44 \%$ of that of males in 2000 over 1996, urban female wage rates decline to $46 \%$ from $50 \%$ over the same time period (LFS, 2000 \& 1995-96). However, relatively little is known about wage differences between the male and female labor force participation in the urban labor market as a whole and the extent to which any gender-based wage gap can be explained by the men's and women's relative endowments in productive and personal characteristics versus outright labor market discrimination. The 
main objective of the study is to estimate the gender wage gap among a large sample of urban workers in Bangladesh using nationally representative cross-section dataset (Bangladesh Labor Force Survey 2010) from Bangladesh. This study also aims to explore whether gender wage gap varies across the wage distribution.

The rest of the article is organized as follows. Section 2 gives a brief literature review. Section 3describes the empirical specifications that are adopted in this study. In section 4, we discuss the summary statistics and the estimation of raw gender wage gap. Section 5 reports the results for our empirical analysis. The paper concludes with a brief summary of findings including the policy implications.

\section{Literature Review}

Wage inequalities between sexes, or races in a country exist due to either differences in their productive skills in addition to the differences in culture, geographic proximity and historical reasons or differences in rewards despite presence of equal endowments of productive skills (Ahmed and Maitra, 2010). These causes of wage inequalities are, in general, attributed to wage inequalities at the workplace (Becker, 1957; Phelps, 1972 and Arrow, 1972). Later on, works in line with wage inequalities by Oaxaca (1973), Blinder (1973), Reimers (1983), Neumark (1988) and Cotton (1988) were influenced by Becker. They all examined and identified active wage discrimination against women in the labor markets of Africa and Eastern \& Central Europe (Psacharpoulos and Tzannatos, 1992; Knight and Sabot, 1982; Appleton et al., 1999; Glick and Sahn, 1997; Brainerd, 1998; Newell andReilly, 2001; Jurajda, 2001; Adamchik and Bedi, 2003). Horton (2002) finds that there are differences in returns to male and female productive factors, which account for half of the wage gaps between them. Jacob (2006) using longitudinal data set (1983 and 1999-2000) from India explores wage gap between caste and gender and concludes that $55 \%$ of the wage gap remains unexplained. Akter (2005) finds that $70 \%$ of the wage gap in Bangladesh is due to within job discrimination. There are few other relevant studies on Bangladesh (Majumder and Zohir, 1993; Majumder and Mahmud, 1994 and Zohir, 1998) which focus on wage gaps only in urban manufacturing sectors. They find the significant differences in the wage rates of men and women but this cannot be explained by the differences in productivity related characteristics and hence, discrimination against women might play a role there. Therefore, a considerable wage gap exists between male and female laborers and it is more rampant in urban areas compared to rural areas in Bangladesh (Ahmed and Maitra, 2010). However, detail studies on urban labor market in Bangladesh as a whole are rarely found. The objective of this study to address this gap by applying more advanced econometric techniques to find robust estimates on the male-female earnings gap.

The literature on decomposition of gender wage gap in developed countries is quite large, but it is relatively scarce in developing countries. Exceptions to this are the studies by Pham and Reilly (2007) for Vietnam, Ganguli and Terrell (2005) for Ukraine and Nopo (2006) for Chile. The most common method of decomposing the gender wage gap is the use of Oaxaca-Blinder decomposition method (see Oaxaca, 1973; Blinder 1973), which decomposes at the mean of 
the wage distribution. However, this might not tell us the full story and there is an alternative that quantifies wage gaps at different points of the wage distribution. Albrecht et al. (2003); Machado and Mata (2005); Miller (2005); Gupta et al. (2006) and Arulampalam et al. (2007) conclude that gender wage gap exists and it varies across the wage distribution. Literature is scarce for the Bangladesh urban labor market that uses the quantile decomposition approach. Moreover, ignoring differences in hours of work would result in a significant overestimation of the gender pay gap. Therefore, it is important for this study to measure raw weekly wage gaps considering weekly hours worked by male and female workers. One of the principal aims of this paper is to address these shortcomings by examining the extent of gender wage gap in Bangladesh urban labor market at different quantiles of a wage distribution and also decompose this gap as per their productive components.

\section{The Empirical Specification}

First of all, this study uses standard Mincerian regression model for the estimation of economic returns to various productive factors such as education as well as the estimation of gender earnings gap after controlling for the differences in age, working hours, education, occupation, industry, and location. The regression specification looks like the followings:

$$
\ln w_{i}=\alpha+\beta_{i} x_{i}+\varepsilon_{i}
$$

The dependent variable is the log of person $i$ 's weekly wage, $w_{i}$. Independent variables include a female dummy, age, age squared, weekly hours worked, 10 education dummies, 10 occupation dummies, 20 industry dummies and the location dummies. The same regression specification is used at each personal characteristic considered in this study in order to explore more details of the gender wage gap.

Secondly, the most commonly used technique for the measuring discrimination against women labor force is the Oaxaca-Blinder decomposition method (Oaxaca, 1973; Blinder, 1973). They decompose the wage differential into two parts: explained and unexplained. Explained wage gap can be explained by differences in personal characteristics of workers and the unexplained component attribute to discrimination.

As decomposition technique starts by estimating wage equations separately for male and female, this study follows the following general specification:

$$
\ln W_{i j}=\alpha_{j}+X_{i j}^{\prime} \beta_{j}+\varepsilon_{i j} ; \quad i=1,2, \ldots \ldots \ldots \ldots \ldots . . ., n ; j=\text { male, female }
$$

$\ln W_{i j}$ is the natural $\log$ of weekly wages, $\alpha_{j}$ is the intercept term for gender group, $X_{i j}^{\prime}$ is a vector is a vector of characteristics of individual $i$ who belong to gender group $j$ and $\beta_{j}$ is a vector of coefficients and $\varepsilon_{i j}$ is the error term. For clarity, given are two groups, male (M) and female (F); an outcome variable, log of weekly wage (W); and a set of predictors such as age, age squared, weekly hours worked, 10 education dummies, 10 occupation dummies, 20 industry dummies and the location dummies. The mean outcome difference can 


\section{Il Macrothink}

be expressed as:

$$
D=E\left(W_{M}\right)-E\left(W_{F}\right)
$$

Here $E(W)$ denotes the expected value of the outcome variable, is accounted for by group differences in the predictors. Based on the linear model

$$
W_{l}=X_{l}^{\prime} \beta+\varepsilon_{l}, \quad E\left(\varepsilon_{l}\right)=0 \quad l \in(\text { male }, \text { female })
$$

Where, $X$ is a vector of the predictors including the constant, $\beta$ contains the slope parameters and the constant, and $\varepsilon$ is the error. Now the mean outcome difference is the difference in the linear prediction at the group-specific means of the regressors. That is,

$$
D=E\left(W_{M}\right)-E\left(W_{F}\right)=E\left(X_{M}\right)^{\prime} \beta_{M}-E\left(X_{F}\right)^{\prime} \beta_{F}
$$

Now the contribution of group differences in the predictors to overall outcome difference can be obtained by the following way (see Jann, 2008; Winsborough and Dickinson, 1971; Jones and Kelley,1984; and Daymont and Andrisani,1984).

$$
D=\left\{E\left(X_{M}\right)-E\left(X_{F}\right)\right\}^{\prime} \beta_{F}+E\left(X_{F}\right)^{\prime}\left(\beta_{M}-\beta_{F}\right)+\left\{E\left(X_{M}\right)-E\left(X_{F}\right)\right\}^{\prime}\left(\beta_{M}-\beta_{F}\right)
$$

Here outcome difference is divided into three parts, namely, endowment effect

$\left[\left\{E\left(X_{M}\right)-E\left(X_{F}\right)\right\}^{\prime} \beta_{F}\right]$, discrimination effect $\left[E\left(X_{F}\right)^{\prime}\left(\beta_{M}-\beta_{F}\right)\right]$ and the simultaneous effect

$\left.\left[E\left(X_{F}\right)\right\}^{\prime}\left(\beta_{M}-\beta_{F}\right)\right]$. This study estimates the first two effects.

Thirdly, we use quantile regression and the decomposition by quantiles in order to provide information about the relationship between the outcome variable, weekly wage (W), and the regressors $\mathrm{X}$ at different points in the conditional distribution of $\mathrm{W}$. The full specification of Mincerian regression is applied for the specified quantiles.

\section{Data and Summary Statistics}

The dataset used in this analysis comes from Bangladesh Labor Force Survey conducted in 2010 (hereafter LFS 2010). This is a nationally representative (cross-sectional) random sample, administered by Bangladesh Bureau of Statistics (BBS). The data contains information on a wide range of individual such as age, sex, marital status, educational attainment, occupational status, hours worked weekly and wage earned weekly and household level characteristics like household size and composition, religion, landholding, location, asset ownership. The estimating sample for the LFS 2010 dataset consists of 199,704 individuals of which 159,296 individuals are from rural and 40,408 are from urban 
areas. Of the 40,408, weekly wage data are available only for 10,764 individuals. This study considers only these individuals in order to explore and meet the objective of the study. Analysis is restricted to individuals aged 15 years and above.

Of the 10,764 urban workers for which weekly wage data are available, $83.71 \%$ is male. This reflects the very low labor force participation and employment rates among the female labor force in urban Bangladesh. The average weekly wage among male workers in the sample is approximately BDT 2,105, as against BDT 1,563 for female workers, representing 34.7\% lower weekly wage for women workers. On the contrary, men work on an average of 54.07 hours per week compared to 51.80 hours for women. Thus, the net lower weekly wage for women workers is approximately $30 \%$ in the urban setting of Bangladesh. Descriptive statistics and the mean differences of the characteristics between men and women are reported in the annex tables $\mathrm{A} 1$ and $\mathrm{A} 2$ respectively.

The average age for women in the sample is 31.7 years as against 36.9 years for men, reflecting lower participation rates of older female workers in the country. The promising feature is that an increasing numbers of younger female labor force are entering into the workforce - particularly in formal wage-based occupations. Between 2000 and2005/6, women employment in formal-sector employment increased from 1.2 to 1.6 million whereas male employment increased to 8.6 from 8.4 million (LFS, $2000 \& 2005 / 6$ ). It is also evident in this study that $38.3 \%$ percent of the sample of women is aged $15-25$ whereas it is $29.7 \%$ percent for men. This implies that younger female labor force is more in favor of access to employment than their predecessors in the urban labor market.

With regard to labor force participation by literacy and education, $40.6 \%$ women are illiterate whereas it is only $29.1 \%$ for men. Up to class Eight (i.e., Eight years of schooling), there are no significant differences in the participation between male and female. Similar results are obtained in cases of Bachelor, Masters, medical, engineering and technical education, where the differences are not significant at $5 \%$ level. From class nine (i.e., nine years of schooling) to HSC (i.e., twelve years of schooling), male labor force participation is higher than that of the female. There are differences in the labor force participation across occupations too. For example, this study finds no female labor force in armed forces. Moreover, no significant differences are observed for technician \& associated professional and crafts \& related trade workers. In cases of professionals and plant, machine operators and assembling, women's participation is significantly higher than the male. With respect to labor force participation, the major industries include manufacturing; wholesale and retail trade \& repair of motor vehicles; transportation and storage; agriculture, forestry \& fishing; construction and education. Male participation rate in those specified major industries are not necessarily more than that of female. Female labor force participation is significantly higher in the manufacturing and in the education industries. With respect to geographical proximity, no significant differences in the labor force participation are observed in Chittagong and Rajshahi division though women participate more in the labor force compared to men. In Dhaka, women's participation rate is significantly higher than that of the males. The reverse picture is true in favor of men in Barisal and Khulna division. 
Regarding wage differentials across ages, this study finds no significant wage differentials at the early stages of entering into the jobs. However, wage differential increases as age increases and this result is particularly true for male labor force. Similarly, there is a positive association between education and wage differential. However, there are no significant wage differentials for medical and engineering \& technical and vocational education. In 5 out of the 10 occupational categories, men earn significantly more than female. These categories include legislators, senior officials and managers; professionals; technicians and associated professionals; service workers, shops and market sales; and plant, machine operators and assembling. Though female participation is more in the manufacturing and education industry, men are earning significantly more than their female counterpart. No significant wage differences are observed for agriculture and transport industries. Wage differentials are visible only in Dhaka and Chittagong divisions, where urbanization is more rapid compared to the other divisions. Detailed findings regarding wage differentials are reported in the annex table A3.

For the estimation of raw gender wage gap, this study uses weekly hours worked and earnings of the male and female workers. Women are likely to work fewer hours than men and this makes a gap in weekly earnings between the two groups substantial even if their hourly wages are the same. Therefore, it is important to observe how much efforts women provide and how much they receive compared to their male counterpart. This helps us identifying raw wage gaps across different characteristics. The following equation is used to estimate the robust raw gender wage gap.

Raw gender wage gap = Female weekly wages as a \% of male-Female weekly hoursas a \% of male

Positive sign implies the gender gap in favor of the women and the opposite is true for the men. Though the earnings gap is positive (1.2\%) for ages between 15 to 25 years, the gap reaches to $-29.2 \%$ for ages 55 and above. This implies men are benefitted more than women as experience increases. Many believe education might play a key role to closing the wage gap. One of the most sobering findings of this study is that more educated women often find themselves on the wrong side of an even bigger pay gap. The highest earnings gap is evidenced for the medical and engineering degree holders, which is approximately $-46 \%$. There are significantly fewer women in highly paid occupations like legislators, senior officials and managers. Highest wage gap is also found for this category (about -39\%). On the contrary, though men and women equally participate in the crafts and related trade works, there is a positive gender earnings gap (about 19\%). Though women participation is more than twice compared to men in the manufacturing industries, women receive, on average, $33 \%$ less compared to men. Similar findings are observed for financial and insurance activities and the education. As per geographical variations, the highest wage gap is observed in Dhaka division (approx. -37\%), which is followed by Chittagong (approx. -27\%). Positive gender wage gaps are found for Barisal (12.5\%), Rajshahi (12.7\%) and Khulna (11.9\%) divisions. See annex table A4 for more detail. 


\section{Results and Discussion}

\subsection{Measuring Gender Wage Gap}

Table 1. Mincer Regression Results from Different Specifications

\begin{tabular}{|c|c|c|c|c|c|}
\hline Variables & $\begin{array}{c}\text { (1) } \\
\text { Model } 1\end{array}$ & $\begin{array}{c}(2) \\
\text { Model } 2\end{array}$ & $\begin{array}{c}\text { (3) } \\
\text { Model } 3\end{array}$ & $\begin{array}{c}(4) \\
\text { Model } 4\end{array}$ & $\begin{array}{c}(5) \\
\text { Model } 5\end{array}$ \\
\hline \multirow[t]{2}{*}{ Female } & $-0.192 * * *$ & $-0.125 * * *$ & $-0.126 * * *$ & $-0.0812 * * *$ & $-0.0773 * * *$ \\
\hline & $(0.0169)$ & $(0.0170)$ & $(0.0171)$ & $(0.0158)$ & $(0.0167)$ \\
\hline \multirow[t]{2}{*}{ Age } & & $0.0499 * * *$ & $0.0499 * * *$ & $0.0334 * * *$ & $0.0325^{* * *}$ \\
\hline & & $(0.00252)$ & $(0.00252)$ & $(0.00239)$ & $(0.00237)$ \\
\hline \multirow[t]{2}{*}{ Age squared } & & $-0.000529 * * *$ & $-0.000529 * * *$ & $-0.000329 * * *$ & $-0.00032 * * *$ \\
\hline & & $(3.21 \mathrm{e}-05)$ & $(3.21 \mathrm{e}-05)$ & $(3.01 \mathrm{e}-05)$ & $(2.96 \mathrm{e}-05)$ \\
\hline \multirow[t]{2}{*}{ Hours per week } & & & -0.000291 & $0.00395 * * *$ & $0.00248 * * *$ \\
\hline & & & $(0.000582)$ & $(0.000548)$ & $(0.000552)$ \\
\hline \multicolumn{6}{|c|}{ Education Dummies (Base category: Class one) } \\
\hline \multirow[t]{2}{*}{ Class two } & & & & $0.122 * * *$ & $0.0929 * * *$ \\
\hline & & & & $(0.0156)$ & $(0.0152)$ \\
\hline \multirow[t]{2}{*}{ Class Three } & & & & $0.240 * * *$ & $0.194 * * *$ \\
\hline & & & & $(0.0177)$ & $(0.0176)$ \\
\hline \multirow[t]{2}{*}{ Class Four } & & & & $0.266 * * *$ & $0.208 * * *$ \\
\hline & & & & $(0.0243)$ & $(0.0240)$ \\
\hline \multirow[t]{2}{*}{ Class five } & & & & $0.489 * * *$ & $0.385 * * *$ \\
\hline & & & & $(0.0255)$ & $(0.0262)$ \\
\hline \multirow[t]{2}{*}{ Class Six } & & & & $0.637 * * *$ & $0.505^{* * *}$ \\
\hline & & & & $(0.0282)$ & $(0.0302)$ \\
\hline \multirow[t]{2}{*}{ Class Seven } & & & & $0.829 * * *$ & $0.654 * * *$ \\
\hline & & & & $(0.0290)$ & $(0.0324)$ \\
\hline \multirow[t]{2}{*}{ Class Eight } & & & & $1.008 * * *$ & $0.822 * * *$ \\
\hline & & & & $(0.0361)$ & $(0.0381)$ \\
\hline \multirow[t]{2}{*}{ Class Nine } & & & & $1.484 * * *$ & $1.246^{* * *}$ \\
\hline & & & & $(0.0920)$ & $(0.0925)$ \\
\hline \multirow[t]{2}{*}{ Class Ten } & & & & $0.846 * * *$ & $0.696 * * *$ \\
\hline & & & & $(0.110)$ & $(0.109)$ \\
\hline Occupation dummy & & & & No & Yes \\
\hline Industry dummy & & & & No & Yes \\
\hline Divisional dummies & & & & No & Yes \\
\hline \multirow[t]{2}{*}{ Constant } & $7.353 * * *$ & $6.316 * * *$ & $6.333 * * *$ & $6.139 * * *$ & $6.628 * * *$ \\
\hline & $(0.00731)$ & $(0.0460)$ & $(0.0564)$ & $(0.0548)$ & $(0.112)$ \\
\hline Observations & 10,764 & 10,764 & 10,764 & 10,764 & 10,757 \\
\hline R-squared & 0.011 & 0.058 & 0.058 & 0.234 & 0.296 \\
\hline
\end{tabular}




\section{MInstitute ${ }^{\text {Mech }}$}

Table 1 provides estimates from Mincerian regressions of 5 different specifications. Specification (1) includes only the female dummy and thus provides the unadjusted gender wage gap. Each of the subsequent regressions add additional explanatory variables including age, age squared, hours worked per week, education dummies, occupation and industry dummies. The raw gender wage gap in the urban Bangladesh, given in specification (1), is 19.2 percent. The exact difference stands at $21.2 \%$ [i.e., $\exp (0.192)-1) * 100$ ]. Adding relevant explanatory variables in the subsequent regressions reduces the gap to $7.7 \%$ (exact $8.0 \%)$. Controlling for differences across hours worked, occupations, industries, and geographical variations have only a minor effect on the estimated gender gap. However, the large reduction in the estimated gender gap is found in this study with the inclusion age, which is used as a surrogate for experience in this study. This implies substantial gender-based segregation across the different age groups and this is clearly comprehensible in our descriptive statistics. Another important factor that can explain gender earnings gap is the education. This is because a large proportion of working women are with no or less education compared to male. Overall, the estimated gender wage gap in this sample of urban wage workers in Bangladesh is $8 \%$ after controlling the influence of all other explanatory variables.

\subsection{Measuring Gender Wage Gaps by Major Characteristics}

Table 2. Mincer Regression Results from Full Specifications by Characteristics

\begin{tabular}{|c|c|c|c|}
\hline Characteristics & $\begin{array}{c}\text { Gender } \\
\text { wage gap }\end{array}$ & Characteristics & $\begin{array}{l}\text { Gender } \\
\text { wage gap }\end{array}$ \\
\hline Age & & Industry & \\
\hline $15-25$ & $.0544926^{*}$ & Agriculture, forestry and fishing & .0258215 \\
\hline $26-35$ & $-.1438599 * * *$ & Manufacturing & $-.0527743 * *$ \\
\hline $36-45$ & $-.181369 * * *$ & Construction & $-.399370 * * *$ \\
\hline $46-55$ & -.0624478 & Wholesale and retail trade & -.0776073 \\
\hline $\mathbf{5 5}^{+}$ & -.0770647 & Transportation and storage & $-.2402065^{* *}$ \\
\hline Education & & financial and insurance activities & -.1439699 \\
\hline Literacy & $-.0700687 * * *$ & Education & $-.152745 * * *$ \\
\hline No education & -.03878 & Occupation & \\
\hline Class i-v & -.0401144 & legislators, senior officials and managers & $-.272145^{* * *}$ \\
\hline Class vi-viii & $-.1695765^{* * *}$ & Professionals & $-.0983573 *$ \\
\hline Class ix-x & .0016608 & Technicians and associated professional & $.1377785^{*}$ \\
\hline SSC/equivalent & -.0413677 & Clerks & -.0350045 \\
\hline HSC/equivalent & -.0556784 & $\begin{array}{l}\text { Service workers and shop and market } \\
\text { sales }\end{array}$ & .0584182 \\
\hline Bachelor degree/equivalent & -.0660851 & Skilled agricultural and fishery worker & -.139016 \\
\hline Master degree/equivalent & $-.1557061 * *$ & Craft and related trade workers & $.1701011^{* * *}$ \\
\hline Medical/engineering degree & -.2652113 & $\begin{array}{l}\text { Plant and machine operators and } \\
\text { assembling }\end{array}$ & $-.149921 * * *$ \\
\hline Technical/vocational education & .2780843 & Elementary occupations & $-.154417 * * *$ \\
\hline
\end{tabular}


Table 2 provides the estimates of gender wage gap after controlling for all factors. For age categories, the largest significant wage gap is found for the age range 36 to 45 years. As the age increases, wage gap increases up to a certain age and then becomes insignificant. The largest gender wage gap is observed in the construction industry (40\%), followed by transportation and storage (24\%) and education (15\%). It is clear that earnings gaps differ substantially across industries and urban women working in all major non-agricultural industries, on average, earn less than men.

\subsection{Decomposition of Gender Wage Gap}

The standard application of the Blinder-Oaxaca technique is to divide the wage gap between male and female labor force into a part that is explained by differences in determinants of wages, such as age and education, and a part that cannot be explained by such group differences. Table 3 reports the twofold decomposition, where the option 'pooled' determines the choice of the reference coefficients, using Blinder-Oaxaca decomposition technique.

Table 3. Results Using Blinder-Oxaca Decomposition

\begin{tabular}{|c|c|c|c|}
\hline $\begin{array}{l}\text { Dependent variable: } \log \\
\text { of wage }\end{array}$ & $\begin{array}{c}\text { (1) } \\
\text { Coefficients } \\
\text { (robust standard errors) }\end{array}$ & $\begin{array}{c}\text { (2) } \\
\text { Exponentiated } \\
\text { coefficients } \\
\text { (robust standard error) }\end{array}$ & $\begin{array}{c}\text { (3) } \\
\text { Coefficients from } \\
\text { survey estimation }\end{array}$ \\
\hline \multicolumn{4}{|l|}{ Panel A: Overall } \\
\hline Men & $\begin{array}{c}7.352602 * * * \\
(.0073195)\end{array}$ & $\begin{array}{c}1560.252^{* * * *} \\
(11.40011)\end{array}$ & $\begin{array}{c}7.373685^{* * * *} \\
(.0078732)\end{array}$ \\
\hline Women & $\begin{array}{c}7.160741^{* * * *} \\
(.0154434)\end{array}$ & $\begin{array}{c}1287.865 * * * \\
(19.70256)\end{array}$ & $\begin{array}{c}7.154836 * * * \\
(.0159734)\end{array}$ \\
\hline Difference & $\begin{array}{c}.1918613 * * * \\
(.0170902)\end{array}$ & $\begin{array}{c}1.211503 * * * \\
(.0205397)\end{array}$ & $\begin{array}{c}.2188486 * * * \\
(.0178083)\end{array}$ \\
\hline Explained & $\begin{array}{c}.1145751 * * * \\
(.0117313)\end{array}$ & $\begin{array}{c}1.121397^{* * * *} \\
(.0131554)\end{array}$ & $\begin{array}{l}.1287129 * * * \\
(.0124581)\end{array}$ \\
\hline Unexplained & $\begin{array}{c}.0772863 * * * \\
(.01657) \\
\end{array}$ & $\begin{array}{c}1.080351 * * * \\
(.0179015) \\
\end{array}$ & $\begin{array}{l}.0901357 * * * \\
(.0174328) \\
\end{array}$ \\
\hline Panel B: Endowments & & & \\
\hline Age & $\begin{array}{c}.0517534 * * * \\
(.0042483)\end{array}$ & $\begin{array}{c}1.053116^{* * * *} \\
(.0044739)\end{array}$ & $\begin{array}{c}.0423566^{* * * *} \\
(.0038823)\end{array}$ \\
\hline Hours worked/week & $\begin{array}{l}.0055674 * * * \\
(.0014354)\end{array}$ & $\begin{array}{c}1.005583^{* * *} \\
(.0014434)\end{array}$ & $\begin{array}{l}.0049276 * * * \\
(.0014058)\end{array}$ \\
\hline Education & $\begin{array}{c}.0377798 * * * \\
(.0062747)\end{array}$ & $\begin{array}{c}1.038503 * * * \\
(.0065163)\end{array}$ & $\begin{array}{c}.0495825 * * * \\
(.006861)\end{array}$ \\
\hline Occupation & $\begin{array}{c}.0350294 * * * \\
(.0062697)\end{array}$ & $\begin{array}{c}1.03565^{* * *} \\
(.0064933)\end{array}$ & $\begin{array}{c}.0440479 * * * \\
(.00704)\end{array}$ \\
\hline Industry & $\begin{array}{l}-.0090611 \\
(.0081012)\end{array}$ & $\begin{array}{c}.9909798 \\
(.0080282)\end{array}$ & $\begin{array}{l}-.0043627 \\
(.0089999)\end{array}$ \\
\hline Division & $\begin{array}{c}-.0064938 * * \\
(.0031946)\end{array}$ & $\begin{array}{l}.9935272 * * \\
(.003174)\end{array}$ & $\begin{array}{l}-.007839 * * \\
(.0031203)\end{array}$ \\
\hline
\end{tabular}




\section{Mll Macrothink}

The decomposition output reports the average predictions by groups and their differences in the first column. In this study, the mean of log wages (lnwage) is 7.35 for men and 7.16 for women, yielding a wage gap of 0.19. This gap is divided into two parts: explained and unexplained. The first part reflects the mean increase in women's wage if they had the same characteristics as men. The increase of 0.115 indicates that differences in age, weekly hours worked, education, occupation and industry account for more than half of the wage gap. The second part quantifies the change in women's wages when applying the men's coefficients to the women's characteristics.

The results from Blinder-Oaxaca decomposition (column 1) are expressed on the logarithmic scale and thus it is sensible to transform the results to the original scale (column 2). Now it shows that the mean wages are BDT 1560.25 and 1287.87 for men and women respectively and hence, the wage gap is $21.2 \%$. Adjusting women's endowments levels to the levels of men increase women's wage by $12.1 \%$ and therefore, a gap of $8 \%$ remains unexplained.

For column 3, survey estimation technique by Oaxaca is used to check robustness of the estimates. Here 'wgt_svrs' variable provides sampling weights for the Bangladesh Labor Force Survey 2010. The estimates from survey estimation are consistent with and close approximation to the previous estimates.

From panel B, it is obvious that the differences in age, education and occupation account for $5.3 \%, 3.9 \%$ and $3.6 \%$ of the explained part of the outcome differential respectively. Moreover, though the differences in hours worked per week and the division play significant role, the magnitudes are not large enough. Finally, industrial segregation based on 21 major groups of the international standard classification of basic industries in Bangladesh does not seem to matter much.

\subsection{Gender wage gap: Quantile Regression Approach}

The quantile regression output for the different quantiles is reported in table 4. The coefficients vary across quantiles. The female coefficients are found highly statistically significant at the two lower conditional quantiles of earnings (Q10 and Q25). Ordinary least square (OLS) coefficient, reported in specification 5 of table 1, differs considerably from the $\mathrm{QR}$ coefficients, even those for median regression. This is the rationale behind using quantile regression. This study uses bootstrapped standard errors from 20 replications.

One reason for coefficients differing across quantiles is the presence of heteroskedastic errors, which is evidenced in this study. The estimated value of chi2(47) is 615.05, which is highly statistically significant. Thus, the null hypothesis of homoskedasticity is soundly rejected and hence, the use of quantile regression is justified. For the hypothesis test of equality of the regression coefficient of female at different conditional quantiles, this study uses simultaneous quantile regression with specified values in the previous quantile regressions. It shows that the estimated value of $F(4,10709)$ is 22.22 , which reject the null hypothesis of coefficient equality. 
Table 4. Quantile Regression Output

\begin{tabular}{|c|c|c|c|c|c|}
\hline Variables & $\begin{array}{l}(1) \\
\text { Q10 }\end{array}$ & $\begin{array}{l}\text { (2) } \\
\text { Q25 }\end{array}$ & $\begin{array}{l}\text { (3) } \\
\text { Q50 }\end{array}$ & $\begin{array}{l}(4) \\
\text { Q75 }\end{array}$ & $\begin{array}{l}\text { (5) } \\
\text { Q90 }\end{array}$ \\
\hline Female & $\begin{array}{l}-0.201 * * * \\
(.0237504)\end{array}$ & $\begin{array}{l}-0.176 * * * \\
(.0246827)\end{array}$ & $\begin{array}{c}-0.0409 \\
(.0228797)\end{array}$ & $\begin{array}{c}0.0262 \\
(.0186914)\end{array}$ & $\begin{array}{c}-0.0339 \\
(.0292352)\end{array}$ \\
\hline Age & $\begin{array}{l}0.0436^{* * * *} \\
(.004949)\end{array}$ & $\begin{array}{l}0.0385^{* * *} \\
(.0038534)\end{array}$ & $\begin{array}{l}0.0389 * * * \\
(.003544)\end{array}$ & $\begin{array}{l}0.0200^{* * * *} \\
(.0037618)\end{array}$ & $\begin{array}{c}0.0119^{* *} \\
(.0047295)\end{array}$ \\
\hline Age squared & $\begin{array}{c}-0.000488 * * * \\
(.0000633)\end{array}$ & $\begin{array}{c}-0.000410 * * * \\
(.0000469)\end{array}$ & $\begin{array}{c}-0.000407 * * * \\
(.0000436)\end{array}$ & $\begin{array}{c}-0.000175^{* * *} \\
(.0000479)\end{array}$ & $\begin{array}{l}-5.95 \mathrm{e}-05 \\
(.0000666)\end{array}$ \\
\hline Hours per week & $\begin{array}{c}0.00372 * * * \\
(.0010577)\end{array}$ & $\begin{array}{c}0.00371 * * * \\
(.0007226)\end{array}$ & $\begin{array}{l}0.00181 * * \\
(.0008199)\end{array}$ & $\begin{array}{c}0.000363 \\
(.0007341)\end{array}$ & $\begin{array}{l}0.00198 * * \\
(.0011062)\end{array}$ \\
\hline \multicolumn{6}{|c|}{ Education Dummies (Base category: Class one) } \\
\hline Class two & $\begin{array}{c}0.0588 * * \\
(.0297716)\end{array}$ & $\begin{array}{l}0.0793 * * * \\
(.0159244)\end{array}$ & $\begin{array}{l}0.0899 * * * \\
(.0175976)\end{array}$ & $\begin{array}{l}0.0857 * * * \\
(.0171128)\end{array}$ & $\begin{array}{c}0.103 * * * \\
(.0256432)\end{array}$ \\
\hline Class Three & $\begin{array}{c}0.114 * * * \\
(.0228676)\end{array}$ & $\begin{array}{c}0.150^{* * * *} \\
(.0160132)\end{array}$ & $\begin{array}{c}0.207 * * * \\
(.0231159)\end{array}$ & $\begin{array}{l}0.184 * * * \\
(.018461)\end{array}$ & $\begin{array}{c}0.213 * * * \\
(.0277305)\end{array}$ \\
\hline Class Four & $\begin{array}{c}0.0928 * * \\
(.0460835)\end{array}$ & $\begin{array}{c}0.170 * * * \\
(.0235546)\end{array}$ & $\begin{array}{c}0.179 * * * \\
(.0211699)\end{array}$ & $\begin{array}{l}0.237 * * * \\
(.039984)\end{array}$ & $\begin{array}{c}0.299 * * * \\
(.0377909)\end{array}$ \\
\hline Class five & $\begin{array}{c}0.242 * * * \\
(.0314214)\end{array}$ & $\begin{array}{c}0.316^{* * * *} \\
(.0262889)\end{array}$ & $\begin{array}{c}0.364 * * * \\
(.0328383)\end{array}$ & $\begin{array}{c}0.392 * * * \\
(.0389421)\end{array}$ & $\begin{array}{c}0.514 * * * \\
(.0637241)\end{array}$ \\
\hline Class Six & $\begin{array}{l}0.342 * * * \\
(.0493985)\end{array}$ & $\begin{array}{l}0.447 * * * \\
(.0512861)\end{array}$ & $\begin{array}{c}0.501 * * * \\
(.0330707)\end{array}$ & $\begin{array}{c}0.494 * * * \\
(.0364872)\end{array}$ & $\begin{array}{c}0.579 * * * \\
(.0497578)\end{array}$ \\
\hline Class Seven & $\begin{array}{c}0.523 * * * \\
(.0595512)\end{array}$ & $\begin{array}{c}0.615^{* * * *} \\
(.0513119)\end{array}$ & $\begin{array}{c}0.594 * * * \\
(.0287765)\end{array}$ & $\begin{array}{c}0.653 * * * \\
(.0504716)\end{array}$ & $\begin{array}{c}0.713 * * * \\
(.0648631)\end{array}$ \\
\hline Class Eight & $\begin{array}{c}0.754 * * * \\
(.0577747)\end{array}$ & $\begin{array}{c}0.822 * * * \\
(.0423604)\end{array}$ & $\begin{array}{c}0.754 * * * \\
(.0439638)\end{array}$ & $\begin{array}{c}0.750 * * * \\
(.0501646)\end{array}$ & $\begin{array}{c}0.942 * * * \\
(.1069198)\end{array}$ \\
\hline Class Nine & $\begin{array}{l}1.020 * * * \\
(.2748855)\end{array}$ & $\begin{array}{l}1.192 * * * \\
(.1165385)\end{array}$ & $\begin{array}{l}1.118 * * * \\
(.1284382)\end{array}$ & $\begin{array}{l}1.299 * * * \\
(.0744646)\end{array}$ & $\begin{array}{c}1.602 * * * \\
(.1315464)\end{array}$ \\
\hline Class Ten & $\begin{array}{c}0.383 * * * \\
(.1779696)\end{array}$ & $\begin{array}{c}0.297 * * * \\
(.1915398)\end{array}$ & $\begin{array}{c}0.792 * * * \\
(.1314965)\end{array}$ & $\begin{array}{c}0.722 * * * \\
(.1339176)\end{array}$ & $\begin{array}{c}0.861 * * * \\
(.2007225)\end{array}$ \\
\hline $\begin{array}{l}\text { Occupation } \\
\text { dummies }\end{array}$ & Yes & Yes & Yes & Yes & Yes \\
\hline Industry dummies & Yes & Yes & Yes & Yes & Yes \\
\hline $\begin{array}{l}\text { Division } \\
\text { dummies }\end{array}$ & Yes & Yes & Yes & Yes & Yes \\
\hline Constant & $\begin{array}{c}5.891 * * * \\
(.4233515)\end{array}$ & $\begin{array}{c}6.376^{* * * *} \\
(.1476057)\end{array}$ & $\begin{array}{c}6.528 * * * \\
(.0995682)\end{array}$ & $\begin{array}{l}7.230 * * * \\
(.119369)\end{array}$ & $\begin{array}{c}7.392 * * * \\
(.1417592)\end{array}$ \\
\hline Observations & 10,757 & 10,757 & 10,757 & 10,757 & 10,757 \\
\hline R-squared & 0.262 & 0.277 & 0.289 & 0.281 & 0.264 \\
\hline
\end{tabular}


The decomposition results based on the unconditional quantile regressions are reported in table 5. We find that the estimated total gender wage gap is higher at lower end of the wage distribution compared to the higher end. Thus the gender wage gap in the urban workers ranges from $6 \%$ to $32 \%$. It is observed that the gender wage gap is lower at $50^{\text {th }}$ quantile of the wage distribution compared to anywhere else on the distribution. For this empirical data, discrimination accounts for the majority of the gender wage gap except for the $50^{\text {th }}$ quantile.

Table 5. Decomposition of Gender Wage Gap by Quintiles

\begin{tabular}{lccccc}
\hline Quartile & Total gap & \% gap & Endowment & Discrimination & Proportion due to discrimination \\
\hline 0.25 & .251279 & 28.57 & .098766 & .152513 & 0.606947 \\
0.50 & .05591 & 5.75 & .085264 & -.029354 & -0.52502 \\
0.75 & .096209 & 10.10 & -.017873 & .112481 & 1.169132 \\
\hline
\end{tabular}

\section{Concluding Comments and Policy Implications}

The main objective of this paper is to examine whether the gender wage gap exists in the urban labor market of Bangladesh. This paper also investigates whether gender wage gap varies across the wage distributions to assess the contribution of different factors that may explain variations in the gender wage gap.

Mincerian OLS regression and its Blinder-Oaxaca decomposition results indicate that women employees are paid less compared to their male counterparts. The estimated wage gap is $21.2 \%$. Adjusting women's endowments levels to the levels of men increase women's wage by $12.1 \%$. Therefore, a gap of $8.0 \%$ remains unexplained. It is obvious from this study that the differences in age, education and occupation each account for 5.3\%, 3.9\% and $3.6 \%$ of the explained part of the outcome differential. Thus, the factors age, education and occupation seem to matter indeed.

The quantile regression output for the different quantile confirms that the coefficients vary across different quintiles and also confirms the presence of heteroskedastic errors in the OLS regression. Hence the ordinary least square (OLS) coefficient differs considerably from the QR coefficients, even those for median regression. This study finds that female coefficients are found highly statistically significant at the two lower conditional quantiles of earnings (Q10 and Q25). Equality of the regression coefficients of female at different conditional quantiles is tested using simultaneous quantile regressions and rejected the null hypothesis of coefficient equality. The decomposition results based on the unconditional quantile regressions find that the estimated total gender wage gap is higher at lower end of the wage distribution compared to the higher end. The gender wage gap in the urban workers ranges from $6 \%$ to $32 \%$. For this empirical data, discrimination accounts for the majority of the gender wage gap except for the $50^{\text {th }}$ quantile.

What causes the gender wage gap and why is the gender wage gap more at the lower tail of the distribution? This might be due to the combination of a number of different factors (e.g. trade unionism, social norms). Unfortunately, the available data does not allow us to elaborate 
on this specific issue. We find that discrimination is a major part of the wage differential along the entire wage distribution. These facts strongly suggest that, although the Bangladesh labor code stipulates equal pay and equal employment opportunity, there is still potential underutilization of women's skills in the labor market. Though legislations have been passed and the government has accepted the role of gender based affirmative action policies in reducing the gender wage gap in Bangladesh, there is still considerable lack of enforcement of these laws. To attain true gender equality, we need stronger enforcement.

\section{References}

Adamchik, V. A., \& Bedi, A. S. (2003). Gender pay differentials during the transition in Poland. Economics of Transition, 11(4), 697-726. https://doi.org/10.1111/j.0967-0750.2003.00162.x

Ahmed, S., \& Maitra, P. (2010). Gender wage discrimination in rural and urban labour markets of Bangladesh. Oxford Development Studies, 38(1), 83-112. https://doi.org/10.1080/13600810903551611

Akter, S. (2005). Occupational Segregation, Wage Discrimination, and Impact on Poverty in Rural Bangladesh. The Journal of Developing Areas, 39(1), 15-39. https://doi.org/10.1353/jda.2005.0031

Albrecht, J., Bjorklund, A., \& Vroman, S. (2003). Is There a Glass Ceiling in Sweden?. Journal of Labor Economics, 21(1). https://doi.org/10.1086/344126

Appleton, S., Hoddinott, J., \& Krishnan, P. (1999). The gender wage gap in three African countries. Economic development and cultural change, 47(2), 289-312. https://doi.org/10.1086/452402

Arrow, K. J. (1972). Models of job discrimination. Racial discrimination in economic life, 83.

Arulampalam, W., Booth, A. L., \& Bryan, M. L. (2007). Is there a glass ceiling over Europe? Exploring the gender pay gap across the wage distribution.Industrial \& Labor Relations Review, 60(2), 163-186. https://doi.org/10.1177/001979390706000201

BBS (1996). Report on Labour Force Survey 1995/96. Dhaka, Bangladesh.

BBS (2006). Report on Labour Force Survey 2005/06. Dhaka, Bangladesh.

Becker, G. S. (2010). The economics of discrimination. University of Chicago press.

Blinder, A. S. (1973). Wage discrimination: reduced form and structural estimates. Journal of Human resources, 8(4), )436-455. https://doi.org/10.2307/144855

Brainerd, E. (1998). Winners and losers in Russia's economic transition.American Economic Review, 1094-1116.

Cagatay, N., \& Özler, S. (1995). Feminization of the labor force: the effects of long-term development and structural adjustment. World development, 11(23), 1883-1894. 
https://doi.org/10.1016/0305-750X(95)00086-R

Cotton, J. (1988). On the decomposition of wage differentials. The review of economics and statistics, 70(2), 236-243. https://doi.org/10.2307/1928307

Daymont, T. N., \& Andrisani, P. J. (1984). Job preferences, college major, and the gender gap in earnings. Journal of Human Resources, 19(3), 408-428. https://doi.org/10.2307/145880

Ganguli, I., \& Terrell, K. (2005). Wage ceilings and floors: The gender gap in Ukraine's transition.

Glick, P., \& Sahn, D. E. (1997). Gender and education impacts on employment and earnings in West Africa: Evidence from Guinea. Economic Development and Cultural Change, 45(4), 793-823. https://doi.org/10.1086/452308

Gupta, N. D., Oaxaca, R. L., \& Smith, N. (2006). Swimming upstream, floating downstream: Comparing women's relative wage progress in the United States and Denmark. Industrial \& Labor Relations Review, 59(2), 243-266. https://doi.org/10.1177/001979390605900204

Horton, S. (Ed.). (2002). Women and industrialization in Asia. Routledge.

Jacob, M. (2006). Changes in the wage gap of gender and caste groups in India.

Jann, B. (2008). The Blinder-Oaxaca decomposition for linear regression models. The Stata Journal, 8(4), 453-479.

Jones, F. L., \& Kelley, J. (1984). Decomposing Differences between Groups A Cautionary Note on Measuring Discrimination. Sociological Methods \& Research, 12(3), 323-343. https://doi.org/10.1177/0049124184012003004

Jurajda, S. (2001). Gender wage gap and segregation in late transition.

Kapsos, S. (2008). The gender wage gap in Bangladesh. ILO Asia-Pacific Working Paper Series.

Knight, J. B., \& Sabot, R. H. (1982). Labor market discrimination in a poor urban economy. $\begin{array}{llll}\text { The Journal of Development } & \text { Studies, }\end{array}$ https://doi.org/10.1080/00220388208421850

Machado, J. A., \& Mata, J. (2005). Counterfactual decomposition of changes in wage distributions using quantile regression. Journal of applied Econometrics,20(4), 445-465. https://doi.org/10.1002/jae.788

Majumder, P., \& Mahmud, S. (1994). Barriers to female employment in urban Bangladesh. Dhaka. Mimeo, Bangladesh Institute of Development Studies (BIDS).

Miller, P. W. (2005). The Role of Gender among Low - Paid and High - Paid Workers. Australian Economic Review, 38(4), 405-417. https://doi.org/10.1111/j.1467-8462.2005.00383.x 


\section{Macrothink}

Neumark, D. (1988). Employers' discriminatory behavior and the estimation of wage discrimination. Journal of Human resources, 23(3), 279-295. https://doi.org/10.2307/145830

Newell, A., \& Reilly, B. (2001). The gender pay gap in the transition from communism: some empirical evidence. Economic Systems, 25(4), 287-304. https://doi.org/10.1016/S0939-3625(01)00028-0

Ñopo, H. (2006). The Gender Wage Gap in Chile 1992-2003 From a Matching Comparisons perspective, IADB. Research Department, Working Paper 562.

Oaxaca, R. (1973). Male-female wage differentials in urban labor markets.International economic review, 14(3), 693-709. https://doi.org/10.2307/2525981

Paul, P., \& Chaudhuri-Zohir, S. (1993). Employment and occupational mobility among women in manufacturing industries of Dhaka city, Bangladesh: findings from a survey of employees. Asian Regional Team for Employment Promotion.

Pham, T. H., \& Reilly, B. (2007). The gender pay gap in Vietnam, 1993-2002: A quantile regression approach. Journal of Asian Economics, 18(5), 775-808. https://doi.org/10.1016/j.asieco.2007.04.001

Phelps, E. S. (1972). The statistical theory of racism and sexism. The american economic review, 62(4), 659-661.

Psacharopoulos, G., \& Tzannatos, Z. (1992). Case studies on women's employment and pay in Latin America. World Bank.

Rahman, K. M. (2013). Women in Labour Force. Accumulation and Alienation: State of Labour in Bangladesh, 127-142.

Reimers, C. W. (1983). Labor market discrimination against Hispanic and black men. The review of economics and statistics, 65(4), 570-579. https://doi.org/10.2307/1935925

Standing, G. (1989). Global feminization through flexible labor. World development, 17(7), 1077-1095. https://doi.org/10.1016/0305-750X(89)90170-8

Winsborough, H. H., \& Dickinson, P. (1971). Components of negro-white income differences. In Proceedings of the Social Statistics Section (Vol. 63, p. 6). American Statistical Association Washington.

Zohir, S. C. (1998). Gender implications of industrial reforms and adjustment in the manufacturing sector of Bangladesh. University of Manchester. 


\section{Appendix}

Table A1: Descriptive statistics

\begin{tabular}{|c|c|c|c|c|c|c|}
\hline \multirow[t]{2}{*}{ Variables } & \multicolumn{2}{|c|}{ Full sample } & \multicolumn{2}{|c|}{ Male } & \multicolumn{2}{|c|}{ Female } \\
\hline & Mean & Std. Dev & Mean & Std. Dev & Mean & Std. Dev \\
\hline Weekly wage received & 2016.503 & 2511.817 & 2104.974 & 2702.685 & 1562.531 & 978.2301 \\
\hline Age & 36.08867 & 12.88224 & 36.93767 & 12.78563 & 31.73215 & 12.49346 \\
\hline Weekly hours worked & 53.68843 & 11.25066 & 54.05676 & 11.2101 & 51.7984 & 11.27191 \\
\hline \multicolumn{7}{|l|}{ Literacy and education } \\
\hline Literacy & .6899218 & .4625469 & .7086255 & .4544209 & .5939463 & .4912351 \\
\hline No education & .2937779 & .4555127 & .2802449 & .4491438 & .363221 & .4810651 \\
\hline Class i-v & .2277385 & .4193925 & .2254869 & .4179258 & .2392918 & .4267731 \\
\hline Class vi-viii & .1626304 & .3690453 & .1637173 & .3700394 & .1570531 & .3639548 \\
\hline Class ix-x & .0798249 & .2710345 & .0839176 & .2772797 & .0588235 & .2353613 \\
\hline SSC/equivalent & .0707899 & .2564855 & .0759043 & .2648596 & .044546 & .2063636 \\
\hline HSC/equivalent & .0582154 & .2341611 & .0611018 & .2395303 & .0434038 & .2038225 \\
\hline Bachelor degree/equivalent & .0572839 & .2323951 & .0589872 & .2356139 & .0485437 & .2149735 \\
\hline Master degree/equivalent & .0396796 & .1952144 & .0398442 & .1956039 & .038835 & .1932566 \\
\hline Medical/Engineering degree & .0065201 & .0804873 & .0067891 & .0821203 & .0051399 & .0715292 \\
\hline Technical/Vocational education & .0035395 & .059391 & .0040067 & .0631749 & .0011422 & .0337869 \\
\hline \multicolumn{7}{|l|}{ Occupation } \\
\hline Armed forces & .0018629 & .043123 & .0022259 & .0471299 & - & - \\
\hline $\begin{array}{l}\text { Legislators, senior officials and } \\
\text { managers }\end{array}$ & .0259873 & .1591048 & .0286032 & .1666979 & .0125642 & .1114158 \\
\hline Professionals & .0612891 & .2398711 & .0524207 & .2228863 & .1067961 & .3089421 \\
\hline $\begin{array}{lll}\text { Technicians associated } \\
\text { professional }\end{array}$ & .0359538 & .1861837 & .0362827 & .1870031 & .0342661 & .1819639 \\
\hline Clerks & .0453614 & .2081052 & .0478575 & .2134766 & .0325528 & .1775138 \\
\hline $\begin{array}{l}\text { Service workers and shop and market } \\
\text { sales }\end{array}$ & .2047317 & .4035243 & .2288258 & .4201002 & .0810965 & .2730613 \\
\hline Skilled agricultural and fishery worker & .0346498 & .1828997 & .038286 & .1918966 & .0159909 & .1254757 \\
\hline Craft and related trade workers & .1377608 & .3446648 & .1363383 & .3431666 & .14506 & .3522619 \\
\hline $\begin{array}{l}\text { Plant and machine operators and } \\
\text { assembling }\end{array}$ & .1561103 & .3629768 & .1255426 & .3313516 & .312964 & .4638323 \\
\hline Elementary occupations & .2962928 & .456643 & .3036171 & .4598449 & .2587093 & .4380507 \\
\hline \multicolumn{7}{|c|}{ Division } \\
\hline Barisal & .055421 & .2288108 & .0594324 & .2364453 & .0348372 & .1834198 \\
\hline Chittagong & .2026826 & .4020167 & .2023372 & .4017647 & .2044546 & .4034177 \\
\hline Dhaka & .4144001 & .4926411 & .4065665 & .4912199 & .4545974 & .4980766 \\
\hline Khulna & .1194113 & .324287 & .1235392 & .3290735 & .0982296 & .2977098 \\
\hline Rajshahi & .1397168 & .3467092 & .1378965 & .3448105 & .1490577 & .3562471 \\
\hline Sylhet & .0683681 & .2523883 & .0702282 & .2555454 & .0588235 & .2353613 \\
\hline
\end{tabular}


Table A2: Mean differences of their characteristics

\begin{tabular}{|c|c|c|c|}
\hline Characteristics & Male & Female & Difference \\
\hline Weekly wage received & 2104.974 & 1562.531 & $542.4433 * * *$ \\
\hline Age & 36.93767 & 31.73215 & $5.205521 * * *$ \\
\hline Weekly hours worked & 54.05676 & 51.7984 & $2.25836 * * *$ \\
\hline \multicolumn{4}{|l|}{ Literacy and education } \\
\hline Literacy & .7086255 & .5939463 & $.1146792 * * *$ \\
\hline No education & .2802449 & .363221 & $-.0829762 * * *$ \\
\hline Class i-v & .2254869 & .2392918 & -.0138049 \\
\hline Class vi-viii & .1637173 & .1570531 & .0066642 \\
\hline Class ix-x & .0839176 & .0588235 & $.0250941 * * *$ \\
\hline SSC/equivalent & .0759043 & .044546 & $.0313583 * * *$ \\
\hline HSC/equivalent & .0611018 & .0434038 & $.0176981 * * *$ \\
\hline Bachelor degree/equivalent & .0589872 & .0485437 & $.0104435^{*}$ \\
\hline Master degree/equivalent & .0398442 & .038835 & .0010092 \\
\hline Medical/engineering degree & .0067891 & .0051399 & .0016492 \\
\hline Technical/vocational education & .0040067 & .0011422 & $.0028645^{*}$ \\
\hline \multicolumn{4}{|l|}{ Occupation } \\
\hline Armed forces & .0022259 & - & - \\
\hline Legislators, senior officials and managers & .0286032 & .0125642 & $.016039 * * *$ \\
\hline Professionals & .0524207 & .1067961 & $-.054375 * * *$ \\
\hline Technicians and associated professional & .0362827 & .0342661 & .0020166 \\
\hline Clerks & .0478575 & .0325528 & $.0153047 * * *$ \\
\hline Service workers and shop and market sales & .2288258 & .0810965 & $.1477293 * * *$ \\
\hline Skilled agricultural and fishery worker & .038286 & .0159909 & $.0222952 * * *$ \\
\hline Craft and related trade workers & .1363383 & .14506 & -.0087216 \\
\hline Plant and machine operators and assembling & .1255426 & .312964 & $-.187421 * * *$ \\
\hline Elementary occupations & .3036171 & .2587093 & $.0449078 * * *$ \\
\hline \multicolumn{4}{|l|}{ Industry classification } \\
\hline Agriculture, forestry and fishing & .1131468 & .0531125 & $.0600343 * * *$ \\
\hline Mining and quarrying & .0057739 & .0017133 & $.0040606 * *$ \\
\hline Manufacturing & .191539 & .4625928 & $-.271053 * * *$ \\
\hline Electricity, gas, steam and air condition & .0056629 & .0017133 & $.0039496 * *$ \\
\hline Water supply; sewerage, waste management & .0009993 & .0011422 & -.0001429 \\
\hline Construction & .0967133 & .0354083 & $.061305 * * *$ \\
\hline Wholesale and retail trade; repair of $\mathrm{m}$ & .1937597 & .0439749 & $.1497848 * * *$ \\
\hline Transportation and storage & .1419054 & .0148487 & $.1270567 * * *$ \\
\hline Accommodation and food service activity & .023873 & .0097087 & $.0141642 * * *$ \\
\hline Information and communication & .0024428 & .0005711 & .0018717 \\
\hline Financial and insurance activities & .0227626 & .0211308 & .0016318 \\
\hline Real estate activities & - & - & - \\
\hline Professional, scientific and technical & .0064402 & .0034266 & .0030135 \\
\hline
\end{tabular}




\begin{tabular}{|l|c|c|c|}
\hline Administrative and support service activities & .0294248 & .0142776 & $.0151473^{* * *}$ \\
\hline Public administration and defense & .0326449 & .0177042 & $.0149407^{* * *}$ \\
\hline Education & .0373085 & .0988007 & $-.061492^{* * *}$ \\
\hline Human health and social work activities & .0123251 & .0285551 & $-.01623^{* * *}$ \\
\hline Arts, entertainment and recreation & .0017766 & .0011422 & .0006344 \\
\hline Other service activities & .0642905 & .0731011 & -.0088106 \\
\hline Activities of households as employers; & .0143238 & .117076 & $-.102752^{* * *}$ \\
\hline Activities of extraterritorial organization & - & - & - \\
\hline Division & \multicolumn{3}{|}{} \\
\hline Barisal & .0594324 & .0348372 & $.0245952^{* * *}$ \\
\hline Chittagong & .2023372 & .2044546 & -.0021174 \\
\hline Dhaka & .4065665 & .4545974 & $-.048030^{* * *}$ \\
\hline Khulna & .1235392 & .0982296 & $.0253096^{* * *}$ \\
\hline Rajshahi & .1378965 & .1490577 & -.0111612 \\
\hline Sylhet & .0702282 & .0588235 & $.0114046^{*}$ \\
\hline
\end{tabular}

Table A3: Wage differentials by gender and characteristics

\begin{tabular}{|c|c|c|c|}
\hline Age category & Male & Female & Difference \\
\hline $15-25$ & 1409.718 & 1412.539 & -2.8216 \\
\hline $26-35$ & 2114.141 & 1647.842 & $466.2984 * * *$ \\
\hline $36-45$ & 2275.06 & 1654.556 & $620.5044 * * * *$ \\
\hline $46-55$ & 2580.761 & 1760.301 & 820.4597 *** \\
\hline $55^{+}$ & 2325.732 & 1495.568 & $830.1637 * *$ \\
\hline \multicolumn{4}{|l|}{ Literacy and Education } \\
\hline Literacy & 2404.866 & 1713.358 & $691.508 * * *$ \\
\hline No education & 1396.167 & 1350.564 & 45.60233 \\
\hline Class i-v & 1614.18 & 1384.63 & $229.5501 * * *$ \\
\hline Class vi-viii & 1915.148 & 1383.916 & $531.2318 * * *$ \\
\hline Class ix-x & 2032.102 & 1512.136 & $519.9662^{* * *}$ \\
\hline SSC/equivalent & 2606.455 & 1892.859 & $713.5956^{* *}$ \\
\hline HSC/equivalent & 3079.585 & 2191.197 & $888.3873^{* *}$ \\
\hline Bachelor degree/equivalent & 3813.877 & 2528.835 & $1285.042 * * *$ \\
\hline Master degree/equivalent & 4726.469 & 2786.324 & $1940.146^{* * * *}$ \\
\hline Medical/engineering degree & 7575.41 & 4055.556 & 3519.854 \\
\hline Technical/vocational education & 3725 & 2725 & 1000 \\
\hline \multicolumn{4}{|l|}{ Occupational categories } \\
\hline Armed forces & - & - & - \\
\hline Legislators, senior officials and managers & 4807.315 & 2481.818 & $2325.497 *$ \\
\hline Professionals & 3446.285 & 2234.048 & $1212.236^{* * *}$ \\
\hline Technicians and associated professional & 2873.261 & 2334.033 & $539.2274 *$ \\
\hline Clerks & 2867.156 & 2582.018 & 285.1383 \\
\hline Service workers and shop and market sales & 2655.083 & 1718.965 & $936.1184 * * *$ \\
\hline
\end{tabular}




\begin{tabular}{|c|c|c|c|}
\hline Skilled agricultural and fishery worker & 1876.948 & 1204.286 & 672.662 \\
\hline Craft and related trade workers & 1582.5 & 1722.106 & -139.6067 \\
\hline Plant and machine operators and assembling & 1766.941 & 1209.195 & $557.7453 * * *$ \\
\hline Elementary occupations & 1391.7 & 1321.28 & 70.41979 \\
\hline \multicolumn{4}{|l|}{ Industry classification } \\
\hline Agriculture, forestry and fishing & 1513.681 & 1438.28 & 75.40149 \\
\hline Mining and quarrying & 1950 & 1666.667 & 283.3333 \\
\hline Manufacturing & 2016.997 & 1352.805 & $664.1916 * * *$ \\
\hline Electricity, gas, steam and air conditioning & 2217.608 & 2016.667 & 200.9412 \\
\hline Water supply; sewerage, waste management & 2070 & 1850 & 220 \\
\hline Construction & 1563.416 & 989.6774 & $573.7382 * * *$ \\
\hline $\begin{array}{l}\text { Wholesale and retail trade; repair of motor } \\
\text { vehicle }\end{array}$ & 2538.127 & 1576.299 & $961.8285^{* *}$ \\
\hline Transportation and storage & 1526.391 & 1215 & 311.3912 \\
\hline Accommodation and food service activity & 1952.298 & 1727.647 & 224.6506 \\
\hline Information and communication & 2850 & 1900 & 950 \\
\hline Financial and insurance activities & 3965.971 & 2660 & $1305.971 *$ \\
\hline Real estate activities & - & - & - \\
\hline Professional, scientific and technical & 4940.948 & 2083.333 & 2857.615 \\
\hline Administrative and support service activities & 3265.442 & 2646 & 619.4415 \\
\hline Public administration & 2410.575 & 2087.097 & 323.4781 \\
\hline Education & 2861.217 & 2007.41 & $853.8069 * * *$ \\
\hline Human health and social work activities & 3299.315 & 2548.8 & 750.5153 \\
\hline Arts, entertainment and recreation & 1627.5 & 1000 & 627.5 \\
\hline Other service activities & 1992.815 & 1640.234 & 352.5808 \\
\hline Activities of households as employers; & 1632.248 & 1549.62 & 82.62855 \\
\hline Activities of extraterritorial organization & - & - & - \\
\hline \multicolumn{4}{|l|}{ Division } \\
\hline Barisal & 2038.408 & 2016.393 & 22.0148 \\
\hline Chittagong & 1830.397 & 1315.517 & $514.8798 * * *$ \\
\hline Dhaka & 2607.472 & 1553.092 & $1054.38 * * *$ \\
\hline Khulna & 1583.826 & 1604.32 & -20.49364 \\
\hline Rajshahi & 1627.345 & 1708.349 & -81.00322 \\
\hline Sylhet & 1897.935 & 1785.951 & 111.9836 \\
\hline
\end{tabular}


Table A4: Wage gaps by characteristics and gender

\begin{tabular}{|c|c|c|c|c|c|c|c|}
\hline & \multicolumn{2}{|c|}{$\begin{array}{l}\text { Weekly hours } \\
\text { worked }\end{array}$} & \multirow{2}{*}{$\begin{array}{c}\text { Female } \\
\text { weekly } \\
\text { working } \\
\text { hours as } \\
\text { a \% of } \\
\text { male }\end{array}$} & \multicolumn{2}{|c|}{ Weekly wage } & \multirow{2}{*}{$\begin{array}{c}\text { Female } \\
\text { weekly } \\
\text { wage as } \\
\text { a \% of } \\
\text { male }\end{array}$} & \multirow[t]{2}{*}{$\begin{array}{l}\text { Wage } \\
\text { gap }\end{array}$} \\
\hline & Male & female & & Male & female & & \\
\hline \multicolumn{8}{|l|}{ Age category } \\
\hline $15-25$ & 54.62332 & 54.0611 & 98.97073 & 1409.718 & 1412.539 & 100.2001 & 1.22937 \\
\hline $26-35$ & 54.68788 & 52.01996 & 95.12155 & 2114.141 & 1647.842 & 77.94381 & -17.1777 \\
\hline $36-45$ & 54.30284 & 49.97143 & 92.0236 & 2275.06 & 1654.556 & 72.72582 & -19.2978 \\
\hline $46-55$ & 52.94401 & 47.42614 & 89.57791 & 2580.761 & 1760.301 & 68.2086 & -21.3693 \\
\hline $55^{+}$ & 51.95845 & 48.56818 & 93.47504 & 2325.732 & 1495.568 & 64.30526 & -29.1698 \\
\hline \multicolumn{8}{|c|}{ Literacy and education } \\
\hline Literacy & 53.8431 & 51.24615 & 95.17682 & 2404.866 & 1713.358 & 71.24547 & -23.9314 \\
\hline No education & 54.75377 & 52.94654 & 96.69935 & 1396.167 & 1350.564 & 96.7337 & 0.03435 \\
\hline Class i-v & 55.60069 & 55.90215 & 100.5422 & 1614.18 & 1384.63 & 85.77916 & -14.763 \\
\hline Class vi-viii & 54.02651 & 50.33091 & 93.15965 & 1915.148 & 1383.916 & 72.26157 & -20.8981 \\
\hline Class ix-X & 55.20159 & 47.70874 & 86.42639 & 2032.102 & 1512.136 & 74.41241 & -12.014 \\
\hline SSC/equivalent & 54.27566 & 47.32051 & 87.18551 & 2606.455 & 1892.859 & 72.62197 & -14.5635 \\
\hline HSC/equivalent & 52.08197 & 48.59211 & 93.29929 & 3079.585 & 2191.197 & 71.15235 & -22.1469 \\
\hline $\begin{array}{l}\text { Bachelor } \\
\text { degree/equivalent }\end{array}$ & 49.74906 & 45.52941 & 91.51813 & 3813.877 & 2528.835 & 66.30615 & -25.212 \\
\hline $\begin{array}{l}\text { Master } \\
\text { degree/equivalent }\end{array}$ & 48.58939 & 45.33824 & 93.30893 & 4726.469 & 2786.324 & 58.95149 & -34.3574 \\
\hline $\begin{array}{l}\text { Medical/engineering } \\
\text { degree }\end{array}$ & 48.13115 & 47.77778 & 99.26582 & 7575.41 & 4055.556 & 53.5358 & -45.73 \\
\hline $\begin{array}{l}\text { Technical/vocational } \\
\text { education }\end{array}$ & 49.47222 & 40 & 80.85346 & 3725 & 2725 & 73.15436 & -7.6991 \\
\hline \multicolumn{8}{|l|}{ Occupation } \\
\hline Armed forces & - & - & & - & - & & \\
\hline $\begin{array}{lr}\text { Legislators, } & \text { senior } \\
\text { officials } & \text { and } \\
\text { managers } & \\
\end{array}$ & 52.00389 & 47.04545 & 90.46525 & 4807.315 & 2481.818 & 51.62587 & -38.8394 \\
\hline Professionals & 48.31423 & 47.34759 & 97.99926 & 3446.285 & 2234.048 & 64.82482 & -33.1744 \\
\hline $\begin{array}{l}\text { Technicians and } \\
\text { associated } \\
\text { professional }\end{array}$ & 49.11963 & 46.46667 & 94.59898 & 2873.261 & 2334.033 & 81.23289 & -13.3661 \\
\hline Clerks & 49.18605 & 43.85965 & 89.17091 & 2867.156 & 2582.018 & 90.05502 & 0.88411 \\
\hline $\begin{array}{l}\text { Service workers and } \\
\text { shop and market } \\
\text { sales }\end{array}$ & 57.03551 & 55.05634 & 96.52993 & 2655.083 & 1718.965 & 64.74242 & -31.7875 \\
\hline
\end{tabular}




\begin{tabular}{|c|c|c|c|c|c|c|c|}
\hline $\begin{array}{l}\text { Skilled agricultural } \\
\text { and fishery worker }\end{array}$ & 52.76163 & 32.89286 & 62.34239 & 1876.948 & 1204.286 & 64.16193 & 1.81954 \\
\hline $\begin{array}{l}\text { Craft and related } \\
\text { trade workers }\end{array}$ & 53.38776 & 47.82283 & 89.57639 & 1582.5 & 1722.106 & 108.8219 & 19.24551 \\
\hline $\begin{array}{l}\text { Plant and machine } \\
\text { operators and } \\
\text { assembling }\end{array}$ & 55.9406 & 56.56204 & 101.1109 & 1766.941 & 1209.195 & 68.43437 & -32.6765 \\
\hline $\begin{array}{l}\text { Elementary } \\
\text { occupations }\end{array}$ & 54.07038 & 52.18543 & 96.5139 & 1391.7 & 1321.28 & 94.94 & -1.5739 \\
\hline \multicolumn{8}{|l|}{ Industry classification } \\
\hline $\begin{array}{l}\text { Agriculture, forestry } \\
\text { and fishing }\end{array}$ & 52.97448 & 46.35484 & 87.5041 & 1513.681 & 1438.28 & 95.0187 & 7.5146 \\
\hline $\begin{array}{l}\text { Mining and } \\
\text { quarrying }\end{array}$ & 49.88462 & 48 & 96.22204 & 1950 & 1666.667 & 85.4701 & -10.7519 \\
\hline Manufacturing & 54.06087 & 54.22963 & 100.3122 & 2016.997 & 1352.805 & 67.07025 & -33.242 \\
\hline $\begin{array}{l}\text { Electricity, gas, } \\
\text { steam and air } \\
\text { conditioning }\end{array}$ & 49.7451 & 45.33333 & 91.13125 & 2217.608 & 2016.667 & 90.93884 & -0.19241 \\
\hline $\begin{array}{l}\text { Water supply; } \\
\text { sewerage, waste } \\
\text { management }\end{array}$ & 52.55556 & 62 & 117.9704 & 2070 & 1850 & 89.37198 & -28.5984 \\
\hline Construction & 52.77842 & 52.5 & 99.47247 & 1563.416 & 989.6774 & 63.30224 & -36.1702 \\
\hline $\begin{array}{l}\text { Wholesale and retail } \\
\text { trade; repair of } \\
\text { motor vehicles }\end{array}$ & 57.16963 & 50.25974 & 87.91336 & 2538.127 & 1576.299 & 62.10481 & -25.8086 \\
\hline $\begin{array}{l}\text { Transportation and } \\
\text { storage }\end{array}$ & 56.73787 & 52.15385 & 91.9207 & 1526.391 & 1215 & 79.59953 & -12.3212 \\
\hline $\begin{array}{l}\text { Accommodation } \\
\text { and food service } \\
\text { activity }\end{array}$ & 59.32558 & 57.23529 & 96.47658 & 1952.298 & 1727.647 & 88.493 & -7.98358 \\
\hline $\begin{array}{l}\text { Information and } \\
\text { communication }\end{array}$ & 53.59091 & 54 & 100.7634 & 2850 & 1900 & 66.66667 & -34.0967 \\
\hline $\begin{array}{l}\text { Financial and } \\
\text { insurance activities }\end{array}$ & 47.49268 & 46.54054 & 97.99519 & 3965.971 & 2660 & 67.07059 & -30.9246 \\
\hline Real estate activities & 50.90909 & - & - & 2995.455 & - & - & - \\
\hline $\begin{array}{l}\text { Professional, } \\
\text { scientific and } \\
\text { technical }\end{array}$ & 52.74138 & 43 & 81.52991 & 4940.948 & 2083.333 & 42.16464 & -39.3653 \\
\hline $\begin{array}{l}\text { Administrative and } \\
\text { support service } \\
\text { activities }\end{array}$ & 48.25283 & 44.64 & 92.51271 & 3265.442 & 2646 & 81.03038 & -11.4823 \\
\hline $\begin{array}{l}\text { Public } \\
\text { administration and }\end{array}$ & 48.48639 & 43.09677 & 88.88426 & 2410.575 & 2087.097 & 86.58088 & -2.30338 \\
\hline
\end{tabular}




\begin{tabular}{|c|c|c|c|c|c|c|c|}
\hline defense & & & & & & & \\
\hline Education & 47.96131 & 47.28324 & 98.58621 & 2861.217 & 2007.41 & 70.15931 & -28.4269 \\
\hline $\begin{array}{l}\text { Human health and } \\
\text { social work } \\
\text { activities }\end{array}$ & 50.87387 & 48.24 & 94.82274 & 3299.315 & 2548.8 & 77.2524 & -17.5703 \\
\hline $\begin{array}{l}\text { Arts, entertainment } \\
\text { and recreation }\end{array}$ & 47.3125 & 32 & 67.6354 & 1627.5 & 1000 & 61.44393 & -6.19147 \\
\hline $\begin{array}{l}\text { Other service } \\
\text { activities }\end{array}$ & 54.0639 & 48.21875 & 89.18844 & 1992.815 & 1640.234 & 82.30739 & -6.88105 \\
\hline $\begin{array}{ll}\text { Activities } & \text { of } \\
\text { households } & \text { as } \\
\text { employers; } & \end{array}$ & 51.85271 & 55.07317 & 106.2108 & 1632.248 & 1549.62 & 94.93778 & -11.273 \\
\hline $\begin{array}{l}\text { Activities of } \\
\text { extraterritorial } \\
\text { organization }\end{array}$ & 50 & - & - & 1962.5 & - & - & - \\
\hline \multicolumn{8}{|l|}{ Division } \\
\hline Barisal & 53.76966 & 46.45902 & 86.40378 & 2038.408 & 2016.393 & 98.91999 & 12.51621 \\
\hline Chittagong & 53.533 & 53.13687 & 99.26003 & 1830.397 & 1315.517 & 71.87058 & -27.3895 \\
\hline Dhaka & 56.0438 & 54.36055 & 96.99655 & 2607.472 & 1553.092 & 59.56313 & -37.4334 \\
\hline Khulna & 51.97838 & 46.4593 & 89.38197 & 1583.826 & 1604.32 & 101.294 & 11.91203 \\
\hline Rajshahi & 52.18725 & 48.0728 & 92.11599 & 1627.345 & 1708.349 & 104.9777 & 12.86171 \\
\hline Sylhet & 51.63233 & 48.86408 & 94.63853 & 1897.935 & 1785.951 & 94.09969 & -0.53884 \\
\hline
\end{tabular}

\section{Copyright Disclaimer}

Copyright for this article is retained by the author(s), with first publication rights granted to the journal.

This is an open-access article distributed under the terms and conditions of the Creative Commons Attribution license (http://creativecommons.org/licenses/by/3.0/). 